\title{
A Multi-Criteria Decision Analytic Model to Determine the Best Candidate for Executive Leadership
}

\author{
Michael F. Frimpon ${ }^{1}$ \\ ${ }^{1}$ Ghana Institute of Management and Public Administration (GIMPA), Accra, Ghana \\ Correspondence: Michael F. Frimpon, Ghana Institute of Management and Public Administration (GIMPA), \\ P.O. Box AH 50, Accra, Ghana. Tel: 23-320-250-4498. E-mail: mfrimpon@gimpa.edu.gh
}

Received: November 28, 2012 Accepted: December 4, 2012 Online Published: February 26, 2013

doi:10.5539/jpl.v6n1p111

URL: http://dx.doi.org/10.5539/jpl.v6n1p111

\begin{abstract}
This paper has two objectives; to come up with a set of attributes that can be used to measure presidential aspirants in a democratic governance system, and to co-opt the attributes so assembled into a mathematical model that can be used to compute the best candidate among a myriad of competing alternatives. The model will have as inputs multiple and disparate criteria which will need to be transformed into dimensionless utilities for meaningful comparisons. The paper espouses why Multi-Criteria Decision Analysis (MCDA), with its variants of MAUT, MAVT and AHP is an appropriate tool to use to accomplish such a task. Constructed piecewise linear functions were used instead of linear Likert scales for better accuracy.
\end{abstract}

Keywords: attributes, leadership, Multi-Criteria Decision Analysis (MCDA), Analytical Hierarchy Process (AHP)

\section{What Is Presidential Leadership?}

American presidential leadership is fundamentally a relational process (Neustadt, 1960) where decisions have considerable consequences for entire societies. The import of this short statement is that the selection of a leader is about the most significant political event on a nation's calendar. In a democratic governance system, where elections are the means through which this function is fulfilled, great expense in resources is invested in this process and rightly so. A great leader can move the nation to the promised land of progress, prosperity and proper nationhood. On the other hand a bad leader can be the antithesis of the ideals spelled above. A bad leader can send the nation to the precipice. Needless wars, internal strife, anarchy and the whittling away of a nation's self worth are mostly the handiworks of bad leadership. Pierce, James Buchanan and Andrew Johnson perennial bottom-five ranked American presidents, wrap around Abraham Lincoln a perennial top-five ranked, showing that good and bad leadership can occur within the same time and space. Pierce and Buchanan are held responsible for a failure to avert the Civil War, the most costly war in American history in terms of lives lost. In effect bad leadership can be costly indeed. A nation should experience economic growth with the passage of time no matter how little, but there are countries, many in the developing world, who's GNPs, have actually gone down with a concomitant reduction in the standard of living of the citizenry decades after independence. This is mostly due to the absence of good leadership. The truth of the matter is, any astute politician can put together an effective campaign team and win elections to become the president of a nation. But not that many have the attributes to become effective in administering the affairs of state, and fewer still have the wherewithal to be great.

After extensive research this is what Jerome Moss an expert in leadership, and the co-author of the Leadership Attributes Inventory [LAI] had to say. "What is much more stable across situations (and over time) than behaviors are the leader's attributes. Attributes act as predispositions, facilitators, and constraints which predispose and shape behaviors in a wide array of tasks, groups, and contexts; the greater the latitude provided by the situation, the more likely it is that attributes will shape behavior" (Moss and Johansen (1991)). In essence, a very good way to predict leadership performance is through an observation of attributes. And that is the purpose of this study. 


\section{Difficulty in Attaining Leadership}

The presidency of a nation is by all measures the ultimate political job. But the presidency is more than a job; it is a calling, which for most people can only be manifested after a life time of commitment to a cause such as a political party.

The holder of this final office commands substantive power like non-other. This is how a historian describes the American president. ' $\ldots$ its officeholder is currently the single most visible political figure in the world and is a custodian of power of which no Caesar or Alexander could have dreamed' (Murray, 99) quoted from Carter, W.S. Clinton Rossiter, another analyst of the "textbook" Presidency, admitted that there is a feeling of veneration, if not exactly reverence," for the authority and dignity of the office and once described Lincoln as "the martyred Christ of democracy's passion play" (Carter, 2010).

'The citizen who "treks across the final frontier toward Presidential prominence and wins presidential power out of a nation comprising millions of citizens commands the embodiment of unyielding and enduring character" (Carter, 2010). This number one citizen must possess a set of characteristics and attributes that should make him that special; for in order to reach this pinnacle, he must have navigated the synclines and anticlines of the political landscape on the uneven road to the ultimate power center. He must have participated in numerous political contests with the penultimate one being his nomination as the flag bearer of his party.

"The office of President will never fall to the lot of any man who is not in an eminent degree endowed with the requisite qualifications. There will be a constant probability of seeing the station filled by characters preeminent for ability and virtue" (Carter, 2010); so said Alexander Hamilton in 1788.

Nevertheless things aren't as nigh impossible to ascend to the presidency as it was in the Hamiltonian days, and even though the job is never handed to anyone on a silver platter, it is possible it can attract questionable characters as well as incompetents who have no business getting near the presidency. Even in non-democratic nations where leadership is bequeathed, there is vigorous grooming of the progenitor because the demands of the job for leading people, usually in the millions, are daunting everywhere. It is now time for there to be a formal process of identifying qualities and attributes that leaders need to be effective because the consequences of choosing bad leaders are dire.

\subsection{Attributes of Presidential Leadership}

There is a wealth of information on the characteristics and attributes of performing US presidents. Polls and surveys have been conducted to identify and discuss these special attributes that characterized the occupants of the hallowed office. Table 1 is sampling of these polls and the respective attributes that were used in their survey instruments.

Certainly individuals also have opinions on what constitute good attributes for rating presidential candidates but this paper will focus on those attributes that are used in polls. The emphasis is on attributes that are useful for measuring presidential candidates, as opposed to measuring sitting presidents and those whose terms are over.

\subsection{Structuring the Process of Selecting Attributes}

The total number of attributes in the grid in Table 1 is 60 . There are similarities in the attributes in the different polls; but some are definitely embedded in others making the list of unequal size. A cross tabulation of the attributes and their sources was done to ensure that a set of unique attributes were identified. Table 2 is the resultant contingency table.

The attributes in Table 2 will be used in the model to evaluate candidates. As a point of interest, the first 13 attributes occurred in more than one poll, with leadership and integrity expectedly having high frequencies of five and four respectively.

\section{Research Methodology: The Case for the Use of Multi-Criteria-Decision Analysis (MCDA) in the Political Arena}

Decision Analysis is the study of identifying and choosing alternatives based on the values and preferences of the decision maker. Making a decision implies that there are alternative choices to be considered, and in such a case we want not only to identify as many of these alternatives as possible but to choose the one that best fits with our goals, objectives, desires, values, and so on. The multi-criteria methodology is a procedure applied to non-structured problems for analysis as well as the documentation of the decision-making process, which is subject to multiple solution alternatives (Harris, 1980; Belton \& Stewart, 2002, Sica et. al, 2008).

Multi-Criteria-Decision Analysis (MCDA) has been used to surmount analytical challenges in Nuclear Waste Remediation, Site selection, Military Logistics, Power generation, land reclamation, public policy and a whole 
lot of more (Kiker et. al, 2009; Keefer et al., 2000, Grelk et al., 1998). But applications of MCDA are expanding as its versatility and power continues to get recognized.

Table 1. Attributes of polls in the US and UK [60] $([\mathrm{x}]=$ number of attributes in poll)

\begin{tabular}{|c|c|c|c|c|c|}
\hline \# & UK Premiers [18] & Arthur Schlesinger [7] & C-Span [10] & Murray-Blessing [5] & SIENA [10] \\
\hline 1 & Leadership skills & $\begin{array}{l}\text { Each held the stage at a critical } \\
\text { moment in history and by timely } \\
\text { action attained timeless results }\end{array}$ & $\begin{array}{l}\text { Public } \\
\text { Persuasion }\end{array}$ & Intelligence & Background \\
\hline 2 & Sound judgment & $\begin{array}{l}\text { Each took the side of liberalism } \\
\text { vs. the status quo }\end{array}$ & Crisis Leadership & Integrity & Imagination \\
\hline 3 & Good in a crisis & $\begin{array}{l}\text { Each was not only a constructive } \\
\text { statesman but also a realistic } \\
\text { politician }\end{array}$ & $\begin{array}{l}\text { Economic } \\
\text { Management }\end{array}$ & $\begin{array}{l}\text { Sensitivity to popular } \\
\text { demands }\end{array}$ & Integrity \\
\hline 4 & Luck & $\begin{array}{l}\text { Each left the executive branch } \\
\text { stronger and more influential } \\
\text { than they found it }\end{array}$ & Moral Authority & Charisma & Intelligence \\
\hline 4 & Decisiveness & $\begin{array}{l}\text { Each offended vested economic } \\
\text { interests and long-standing } \\
\text { popular prejudices }\end{array}$ & $\begin{array}{l}\text { International } \\
\text { Relations }\end{array}$ & Political skill & Luck \\
\hline 6 & $\begin{array}{l}\text { Stable } \\
\text { parliamentary } \\
\text { majority }\end{array}$ & $\begin{array}{l}\text { Each (with the exception of } \\
\text { Lincoln) came from the upper } \\
\text { social strata of society }\end{array}$ & $\begin{array}{l}\text { Administrative } \\
\text { Skills }\end{array}$ & & $\begin{array}{l}\text { Willingness to } \\
\text { take risks }\end{array}$ \\
\hline 7 & $\begin{array}{l}\text { Good quality } \\
\text { colleagues }\end{array}$ & $\begin{array}{l}\text { Most (exceptions being } \\
\text { Washington and Wilson) were } \\
\text { not good } \\
\text { administrators---believing the } \\
\text { ends of policy more important } \\
\text { than the machinery for achieving } \\
\text { them }\end{array}$ & $\begin{array}{l}\text { Relations with } \\
\text { Congress }\end{array}$ & & $\begin{array}{l}\text { Compromisin } \\
\mathrm{g}\end{array}$ \\
\hline 8 & $\begin{array}{l}\text { Understands } \\
\text { problems facing } \\
\text { Britain }\end{array}$ & & $\begin{array}{l}\text { Vision/Setting an } \\
\text { Agenda }\end{array}$ & & Executive \\
\hline 9 & Integrity & & $\begin{array}{l}\text { Pursued Equal } \\
\text { Justice For All }\end{array}$ & & Leadership \\
\hline 10 & $\begin{array}{l}\text { Practices Cabinet } \\
\text { government }\end{array}$ & & $\begin{array}{l}\text { Performance } \\
\text { within the } \\
\text { Context of the } \\
\text { Time }\end{array}$ & & $\begin{array}{l}\text { Communicati } \\
\text { on }\end{array}$ \\
\hline
\end{tabular}

11 Charisma In touch with
ordinary people

UK Survey [5]

Ridings-McIver [5]

13 Ruthlessness Vision/agenda-setting

Leadership qualities

14 Poor opposition Domestic leadership

Accomplishments \& crisis management

Political skill 


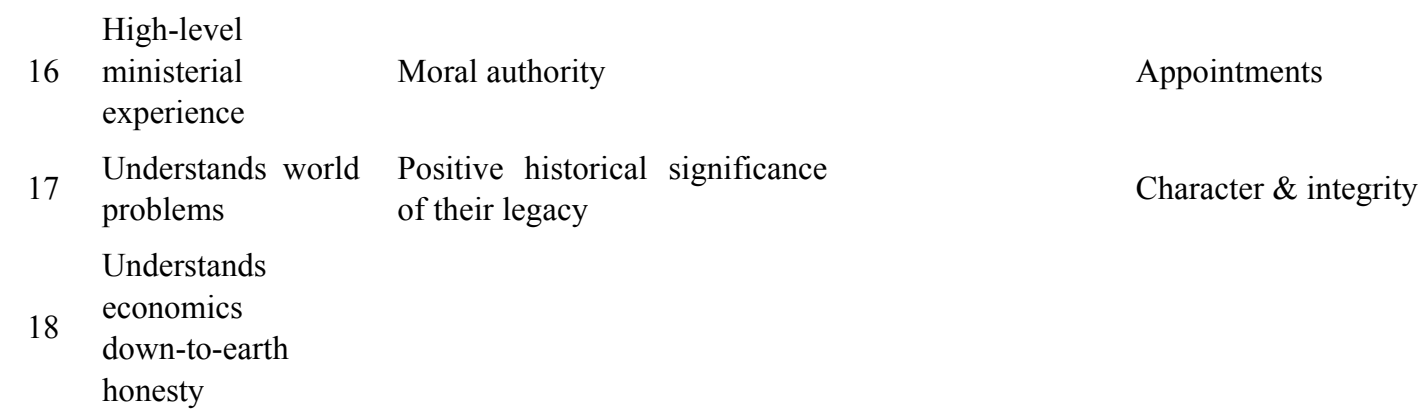

Table 2. Contingency table of unique presidential attributes and sources

\begin{tabular}{|c|c|c|c|c|c|c|c|c|c|}
\hline \# & ATTRIBUTE & $\begin{array}{l}\text { Ridings- } \\
\text { McIver }\end{array}$ & C-Span & Schlesinger & SIENA & $\begin{array}{c}\text { Murray-B } \\
\text { lessing }\end{array}$ & $\begin{array}{c}\text { UK } \\
\text { Premiers }\end{array}$ & $\begin{array}{c}\text { UK } \\
\text { Survey }\end{array}$ & TOTAL \\
\hline 1 & Leadership & 1 & 1 & & 1 & & 1 & 1 & 5 \\
\hline 2 & Integrity & 1 & & & 1 & 1 & 1 & & 4 \\
\hline 3 & Administrative Skills & & 1 & 1 & 1 & & & & 3 \\
\hline 4 & Background & 1 & & 1 & 1 & & & & 3 \\
\hline 5 & Imagination & & 1 & & 1 & & & 1 & 3 \\
\hline 6 & Charisma & & 1 & & & 1 & 1 & & 3 \\
\hline 7 & Appointments & 1 & & & & & 1 & & 2 \\
\hline 8 & Compromising & & 1 & & 1 & & & & 2 \\
\hline 9 & Intelligence & & & & 1 & 1 & & & 2 \\
\hline 10 & Luck & & & & 1 & & 1 & & 2 \\
\hline 11 & Moral Authority & & 1 & & & & & 1 & 2 \\
\hline 12 & Political skill & 1 & & & & 1 & & & 2 \\
\hline 13 & Strong Convictions & & & 1 & & & 1 & & 2 \\
\hline 14 & Experience & & & & & & 1 & & 1 \\
\hline 15 & Anti-Status Quo & & & 1 & & & & & 1 \\
\hline 16 & Communication & & & & 1 & & & & 1 \\
\hline 17 & Decisiveness & & & & & & 1 & & 1 \\
\hline 18 & Economic Philosophy & & 1 & & & & & & 1 \\
\hline 19 & Judgment & & & & & & 1 & & 1 \\
\hline 20 & Machiavellianism & & & & & & 1 & & 1 \\
\hline 21 & Not Risk Averse & & & & 1 & & & & 1 \\
\hline 22 & Sensitivity & & & & & 1 & & & 1 \\
\hline 23 & Statesman & & & 1 & & & & & 1 \\
\hline 24 & Understanding & & & & & & 1 & & 1 \\
\hline
\end{tabular}


An electoral process involves multiple criteria and multiple tradeoffs between criteria in order to arrive at an informed decision of best candidate. 'A multi-criteria problem obeys a canonic and hierarchical form, in which a target can be optimized by specific aims which themselves are quantified by attributes or criteria. Thus, a criterion should be measurable and, therefore, characterized by one or another cardinal scale'. (Keeney and Raiffa, 1993; Chankong and Haimes, 1983)

Electing a president is definitely a multi-criteria problem that lends itself to the tools of MCDA. In an electioneering process, the diverse and disparate candidate attributes are almost impossible to compare unless they can be transformed into dimensionless utilities/values, and this is where MCDA finds its strongest suit over parametric statistics.

Ratings have been the tool of preference since the early Schlesinger days; just around the period when George Dantzig introduced the Simplex method to help in the war and post-war efforts. The statement below by the junior Schlesinger shows that something akin to MCDA in politics has been in the thoughts of academics since the early days. "Meanwhile, scholars continued to play the rating game. Some felt that ratings on the Schlesinger basis were unduly impressionistic and subjective. Quantitative history was coming into vogue. Also political scientists, with their faith in typologies and models, were joining the fun. Would not the results be more "scientific" if presidents were given numerical scores against stated criteria? Then feed the figures into the computer'? (Schlesinger Jnr., 1997). The lack of objectivity due to the qualitative nature of the inputs into the rating process has been controversial and elicited strong rebuttals from opposing camps of scholars. 'Over the years, many other studies have appeared criticizing the whole idea of ranking presidents as meaningless (trying to 'measure the immeasurable'); alleging that such an exercise has a built-in bias towards so-called 'activist' presidents or that the respondents' political orientations skew the results ('a Harvard-eastern elitist-Democratic plot', thundered one critic)' 'Trying to comparatively assess prime ministerial performance and rating the leaders of the past was simply 'the ultimate parlor game for political junkies' (Riddell, 2004; Theakston and Gill, 2005). Operations Research (OR) of which the Simplex is a pivot has now come of age and MCDA, a member of the OR family is as good a tool as any, for managing the analytical complexities in the political domain.

According to Baker et al. (2001), a general decision making process can be divided into the following steps:

Step 1: Define the Problem

Step 2: Determine requirements

Step 3: Establish goals

Step 4: Identify alternatives

Step 5: Define criteria

Step 6: Select a decision making tool

Step 7: Evaluate alternatives against criteria

Step 8: Validate solutions against problem statement

\subsection{Define the Problem}

Politics is a very convoluted process. The selection of an executive leader through democratic elections is a high entropy undertaking involving competing alternatives and a plethora of criteria most of them conflicting. Attempts have been made by scholars and historians to evaluate previous American chief executives and to a lesser extent their British counterparts. Scholars from all walks of life have taken part in many Presidential "greatness" polls, answering questions as simple as "Who are the greatest Presidents of all time?" to filling out complex surveys on topics of Presidential leadership qualities and attributes. This paper is very America-skewed because the US is about the only country where scholars have done due diligence in attempting the process of measuring and ranking their executive leaders. The UK may have a longer democratic tradition but there not much information outside the archives of Westminster. Nevertheless, there is some information in the UK about the attributes of the previous occupants of No.10 Downing Street, and this has been incorporated in this study.

The paper recognizes an opportunity to improve the process of electing executive leaders by introducing tried and tested multi-criteria decision-analytic methods into the fray.

\subsection{Determine Requirements}

Requirements are conditions that any acceptable solution to the problem must meet. They are pre-agreed on conditions that all alternatives must satisfy. A classic requirements document is CERCLA; the set of rules, 
conditions and constraints that govern the remediation of nuclear waste by Department of Energy (DOE) approved remedial alternatives (Grelk, 1998) in the United States.

In the United States, the country of birth requirement is one of the constraints that preclude some hitherto qualified people from contesting the presidency. For example, because of this requirement, neither Henry Kissinger nor Arnold Schwarzenegger can ever be president of the United States even though both rose to highest positions of authority. Age is universal requirement. For example, in most countries with democratic governance systems, there is a minimum age requirement that precludes the young from getting considered for the position. This age requirement is laughably moot in countries in the $3^{\text {rd }}$ world because, as seen in Figure 1, the young can't even sniff the presidency. The assemblage of such requirements as "minimum age, country of birth" and others constitute the constraint or requirement set that govern the evaluation. This set can be used to pare down the alternative set to a manageable size in situations where it is too large.

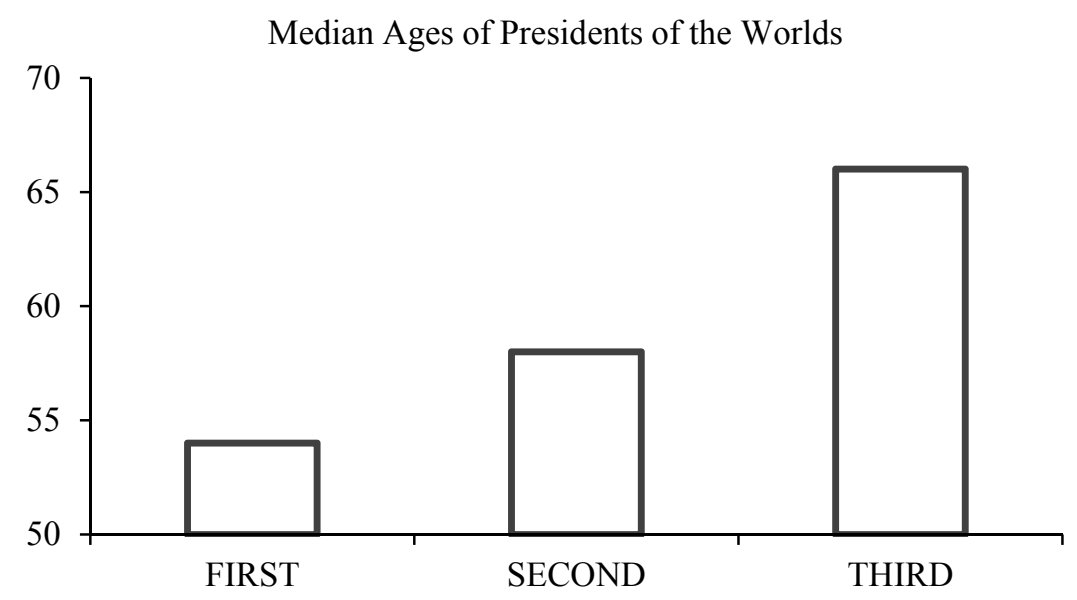

Figure 1. Presidential ages of the worlds: 2010

\subsection{Establish Goals}

Goals are broad statements of intent and desirable programmatic values (Fülöp, 2009). The main goal is to "Determine the best candidate for executive leadership of a nation". In addition we want the leader to be able to steer the ship of state through the tempests that are inevitable. That is why we don't want just any person but a special someone with the qualities to do the job. The conundrum is that we want someone who is just like us whilst being better than us by exhibiting the highest in all attributes.

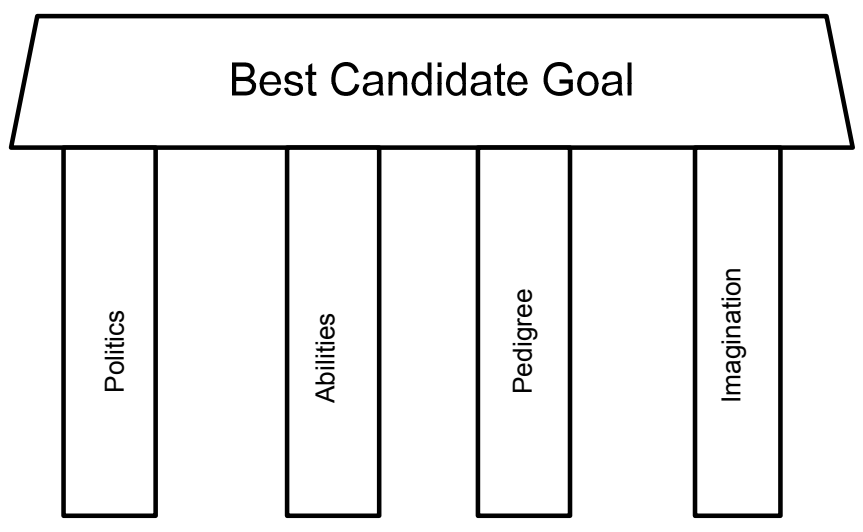

Figure 2. Graphic of the pillars of best candidate 
We desire someone to have the best professional and family background, and the highest integrity and convictions and judgment among others. In effect someone with the highest pedigree.

We desire our leader to have the leadership skills to lead, and the executive ability to administer and manage the labyrinthine complexities that comprise this ship, which means he must have strong abilities.

We desire someone with the soothing balm to make us feel good even when he is increasing our taxes and asking us to make sacrifices. Even whilst campaigning on a partisan platform we want to feel he is the father of the nation. We even desire him to be Machiavellian, so he gets right things done regardless of the means if it is for the good of the country, which means he must have the right politics.

We want a good present for us and better future for our children. Our leader must craft interventions to ease our burden and map the way forward with a compelling vision of the future. Yes he must have imagination.

These sub goals or 'clusters of attributes' will be pillars upon which he will lean to succeed as captured in the graphic in Figure 2.

\subsection{Identify Alternatives}

Generally the alternatives in the election process are the set $A=\left\{A_{1}, A_{2}, \ldots, A_{m}\right\}$, which is different for each country and each election. For this paper, we take as the alternatives the flag bearers of the ' $\mathrm{m}$ ' political parties that are vying for the position of President, Prime Minister, Chancellor or any executive political office. Below is a sampling of alternatives from a few countries with recent past or impending democratic elections.

United States (Barack Obama, Milt Romney);

United Kingdom (David Cameron, Nick Clegg, Gordon Brown);

Ghana (Abu Sakara, Akuffo Addo, John Mahama, Kwesi Nduom, Hassan Ayariga);

Nigeria (Goodluck Jonathan, Muhammadu Buhari, Nuhu Ribadu, Pat Utomi, Ibrahim Shekarau, Peter Nwangwu, Dele Momodu );

Russia (Sergey Mironov, Mikhail Prokhorov, Vladimir Putin, Vladimir Zhirinovsky, Gennady Zyuganov);

France (Francois Hollande, Nicolas Sarkozy, Marine Le Pen, Jean-Luc Melenchon, Francois Bayrou, Eva Joly); Australia (Julia Gillard, Tony Abbott);

This section simply shows that, in the political domain, there are no scenarios to envisage a non-finite alternative set A.

\subsection{Define Criteria}

Decision criteria, which will discriminate among alternatives, must be based on the goals. It is necessary to define discriminating criteria as objective measures of the goals to measure how well each alternative achieves the goals (Fülöp, 2009). Since the goals will be represented in the form of criteria, every goal must generate at least one criterion but complex goals may be represented only by several criteria.

It can be helpful to group together criteria into a series of sets that relate to separate and distinguishable components of the overall objective for the decision. This is particularly helpful if the emerging decision structure contains a relatively large number of criteria. Grouping criteria can help the process of checking whether the set of criteria selected is appropriate to the problem, can ease the process of calculating criteria weights in some methods, and can facilitate the emergence of higher level views of the issues. It is a usual way to arrange the groups of criteria, sub criteria, and sub-sub criteria in a tree-structure (UK DTLR (2001)).

We place the criteria, into the goals and sub goals as defined above. Also merely placing the criteria in itself brings structure to the process, and again decreases computational intensity (Frimpon, 2012).

Figure 3 is a graphic that captures the essence of the discussions above.

\subsection{Select a Decision Making Tool}

'Decision analysis provides a systematic quantitative approach to making better decisions, rather than a description of how unaided decisions are made (Keefer, 2000)'. This exploratory study is about expanding the frontiers of decision analysis to include politics, an area littered with unknown minefields and fascinating lexicographic terms such as Machiavellianism. It is about computing good leadership based on identified attributes.

MCDA has many variants. There is MAUT, MAVT and AHP, and of course many others that won't be of mention in this paper. 

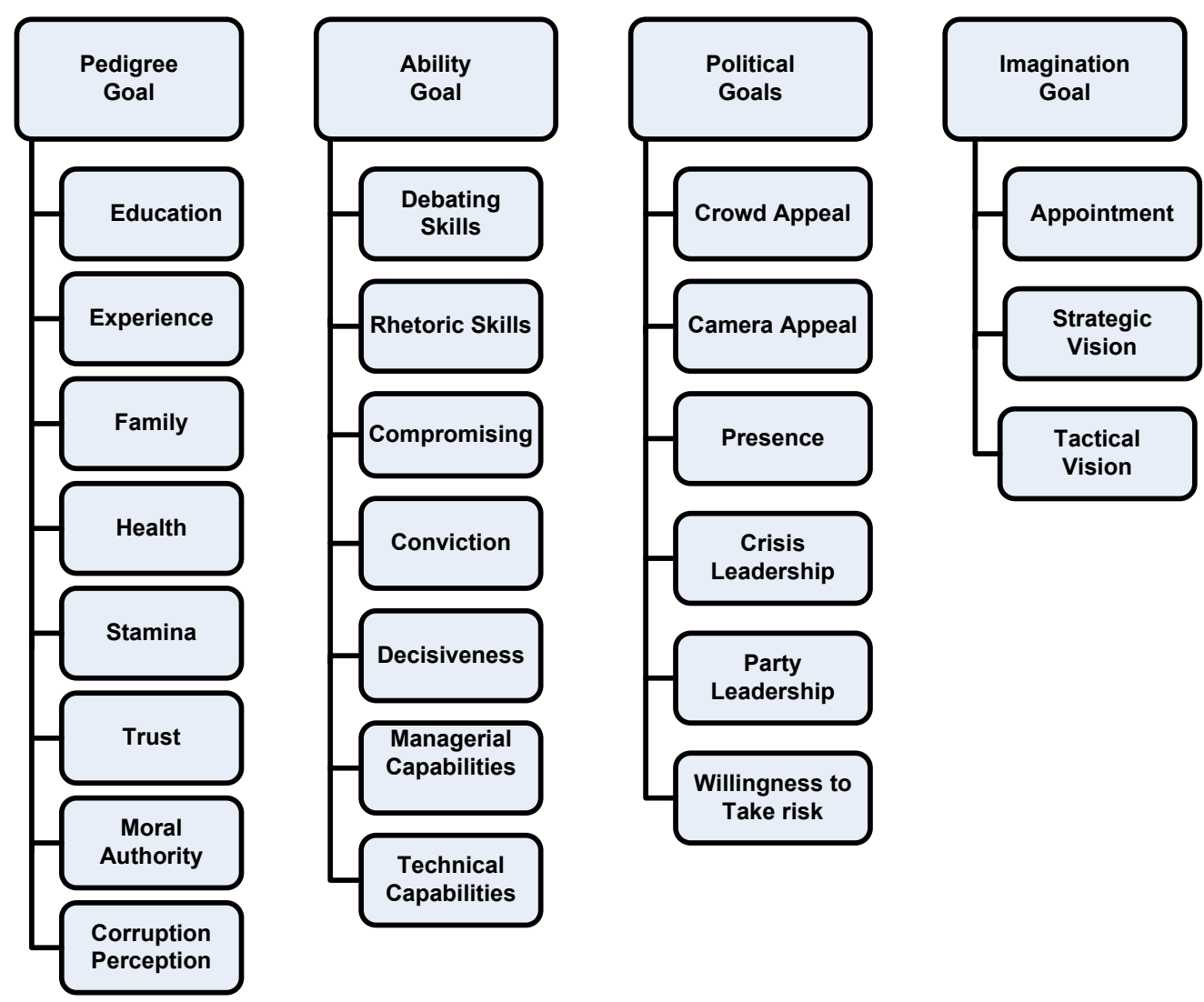

Figure 3. The critical success factors (CSFs) of presidential aspirants

\subsubsection{AHP, a Brief Introduction}

The objective of AHP is to select the alternative that results in the greatest value of the objective function. AHP is also a compensatory optimization approach because alternatives that are deficient with respect to one or more criteria can compensate by their good performance with respect to other criteria. AHP uses a quantitative comparison method that is based on pair-wise comparisons of decision criteria, rather than utility and weighting functions. All individual criteria must be paired against all others and the results compiled in matrix form.

Table 3. Saaty's 9-point scale (with inverses appended for ease of use)

\begin{tabular}{ccc}
\hline SCALE $($ CXX) & STATEMENT & INVERSE (1/CXX) \\
\hline 1 & Equal importance & 1 \\
2 & Between Equal and Moderate & 0.50 \\
3 & Moderate importance of one over another & 0.33 \\
4 & Between Moderate and Strong & 0.25 \\
5 & Strong or essential importance & 0.20 \\
6 & Between Strong and Very Strong & 0.17 \\
7 & Very strong or demonstrated importance & 0.14 \\
8 & Between Very Strong and Extreme & 0.13 \\
9 & Extreme importance & 0.11 \\
\hline
\end{tabular}


AHP uses Saaty's 9-point numerical scale (Table 3) to compare the choices, and the method moves systematically through all pairwise comparisons of criteria as in Table 4 and Table 5 . The formula $n(n-1) / 2$ gives the number of comparisons to be made (in the white cells). For the grid below with $n=4$, the user is only responsible for $(4(4-1) / 2)=6$ inputs. The diagonal cells $c_{x x}$ have values of a 1 each; comparing any criteria with itself gives a 1 .

The grey cells can be configured to be automatically computed upon entry of inputs in the white cells by means of the function $I F(C 12=$ "", "",1/C12) (where C12 is taken as the representative cell). The grey cells are thus merely the inverses of the white cells. The grid is then normalized and averaged to obtain the priorities or weights. Appropriate checks are made to ensure transitivity and consistency. A consistency ratio (CR) of 0.02 implies there is consistency in the decision maker's answers.

Table 4. An AHP inputting process

\begin{tabular}{|c|c|c|c|c|}
\hline CRITERIA & Pedigree & Abilities & Politics & Imagination \\
\hline Pedigree & C11 & $\mathrm{C} 12$ & $\mathrm{C} 13$ & C14 \\
\hline Abilities & $1 / \mathrm{C} 12$ & $\mathrm{C} 22$ & $\mathrm{C} 23$ & $\mathrm{C} 24$ \\
\hline Politics & $1 / \mathrm{C} 13$ & $1 / \mathrm{C} 23$ & $\mathrm{C} 33$ & $\mathrm{C} 34$ \\
\hline Imagination & 1/C14 & $1 / \mathrm{C} 24$ & $1 / \mathrm{C} 34$ & C44 \\
\hline
\end{tabular}

Table 5. An AHP inputting process with example data.

\begin{tabular}{lccccc}
\hline CRITERIA & \multicolumn{1}{c}{ Pedigree } & Abilities & Politics & Imagination & Priorities \\
\hline Pedigree & 1 & 0.25 & 0.3 & 0.6 & $10 \%$ \\
Abilities & 4 & 1 & 0.5 & 2 & $30 \%$ \\
Politics & $31 / 3$ & 2 & 1 & 3 & $45 \%$ \\
Imagination & $12 / 3$ & $1 / 2$ & $1 / 3$ & 1 & $15 \%$ \\
\hline
\end{tabular}

Table 5 also shows the weights and priorities with an acceptable critical ratio of 0.02 .

Weight determination is usually the most contentious in multi-criteria environments. AHP's pairwise method is indirect and can reduce bias or the semblance of it much better than direct elicitation (Schmitt et. al.). The requirement of transitivity, using 'Consistency checks', makes the process more transparent and less nuanced.

\subsubsection{MAUT and MAVT}

MCDA methods such as MAUT and MAVT utilize a decision matrix to provide a systematic analytical approach for integrating risk levels, uncertainty, and valuation, which enables evaluation and ranking of many alternatives. The optimization approach employs numerical scores to communicate the merit of each option on a single scale. Scores are developed from the performance of others. Through the use of utility or value functions, the MCDA method transforms diverse criteria into one common scale of utility or value. Like AHP, these methods are compensatory. The goal of decision-makers in this process is to maximize utility or value.

MAVT is appropriate when there are multiple, conflicting objectives and no uncertainty about the outcome (performance value w.r.t. attribute) of each alternative. The assumption here is that there is functional relationship between attributes and accomplishments. The prediction part makes it probabilistic and thus elements of uncertainty will come into play hence the appropriateness of MAUT. Also the alternatives are human, and humans have more risk factors and uncertainties which make the MAUT more appropriate. MAUT will be used to combine the criteria scores into one multi-attribute utility, based upon which the alternatives will be ranked. The MAUT/MAVT computations are of similar strength, for one is not merely a simplification of the other. This process of determining which of the candidates is best equipped to lead fits all the requirements and steps of Multi-Criteria Decision Analysis (MCDA).

\subsubsection{Single-Dimensional Value / Utility Functions (SDFs)}

The utility function, presented by Keeney and Raiffa (8) and Dyer (9), is the mathematical representation of the decision maker's preference structure, incorporating the means of action in situations of uncertainty. The utility 
function is represented by a normalized variable, in which zero is associated with the worst acceptable consequence, and the value of one with the best possible consequence.

SDFs $v_{i j}$ are used to transform levels of a criterion into a dimensionless quantity called utility in such a way that a utility of zero is assigned to the worst level, and a ' 1 ' for the best level. The intermediate levels are assigned utilities between $(0,1)$. That is; if the worst level is $\mathrm{x}_{-0}$ and the best level is $\mathrm{x}_{+0}$, then

$$
v_{i j}\left(x_{-0}\right)=0 ; \quad v_{i j}\left(x_{+0}\right)=1
$$

We further assume that $v_{i j} \geq 0$ for all $\mathrm{i}$ and $\mathrm{j}$, and that the higher value of $v_{i j}$, the more desirable.

The Merriam-Webster Dictionary defines a metric as "a basis or standard of comparison". For a metric to be useful, functional levels ought to be developed. Thus to capture the educational background of an alternative, levels of education are determined and the corresponding utilities are calculated as in Table 6 .

Table 6. Example Metric ‘Education' with Levels and Shape
a) No Education
b) HND
c) Bachelors
d) Masters
e) Doctorate

a) $\quad$ (No Education $)=0$;

b) $\mathrm{v}(\mathrm{HND})=.5$

c) $\mathrm{v}($ Bachelors $)=0.75$

d) $\quad$ (Masters $)=0.9$

e) $\quad \mathrm{v}($ Doctorate $)=1$

Levels of Education in Utils

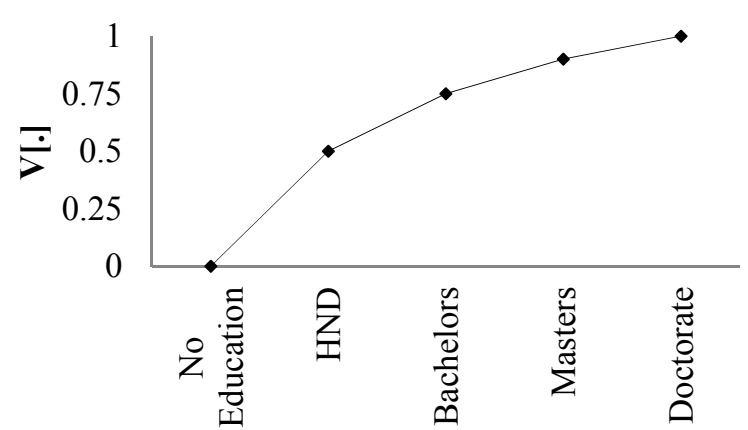

This particular education function ' $\mathrm{v}$ ' is a piecewise linear cumulative distribution function that follows the 'decreasing marginal utility' principle; there is more utility in moving from 'no education' to HND, than from 'HND to bachelors'; the same way there is more joy in moving from 'zero to the first million dollars' than in moving from the $50^{\text {th }}$ million to $51^{\text {st }}$ million (for millionaires) even though they are each a 'net' million.

For this study, the functions are designed and constructed to be mostly monotonic piecewise linear.

The Existence theorem establishes that there is a value function, $V\left(a_{n}\right)$ for, $n$, alternatives assessed according to the, $i$, criteria with the following property:

$V\left(a_{1}\right)>V\left(a_{2}\right) \rightarrow a_{1}>a_{2}$

$V\left(a_{1}\right)=V\left(a_{2}\right) \rightarrow a_{1}=a_{2}$

$V\left(a_{1}\right)<V\left(a_{2}\right) \rightarrow a_{1}<a_{2}$

Obviously for the metric 'Education'

$0.5>0 \rightarrow \mathrm{HND}>$ No Education

In this way, it is possible to produce a hierarchy of the alternatives, $a_{n}$, that is, if the value of alternative $a_{1}$ is greater than that of alternative $a_{2}$, then alternative $a_{1}$ is more appealing than alternative $a_{2}$. (Sica et al,)

The decreasing marginal utility principle affirms that, as one good is more consumed, each additional quantity consumed will provide additions that are increasing less in utility

\subsection{Evaluate Alternatives against Criteria}

Alternatives are measured on the criteria to determine how well they perform on each one. Table 7 below is a way to systematically go through the measurement process.

pij, is the score of alternative $\mathrm{j}$ on criteria $\mathrm{i}$; where criteria is from sub goal $\mathrm{P}$

$\mathrm{xij}$, is the score of alternative $\mathrm{j}$ on criteria $\mathrm{i}$; where criteria is from sub goal $\mathrm{X}$. 
$\mathrm{zij}$, is the score of alternative $\mathrm{j}$ on criteria $\mathrm{i}$; where criteria is from sub goal $\mathrm{Z}$

Table 7. Evaluation of alternatives on Sub goals and Criteria

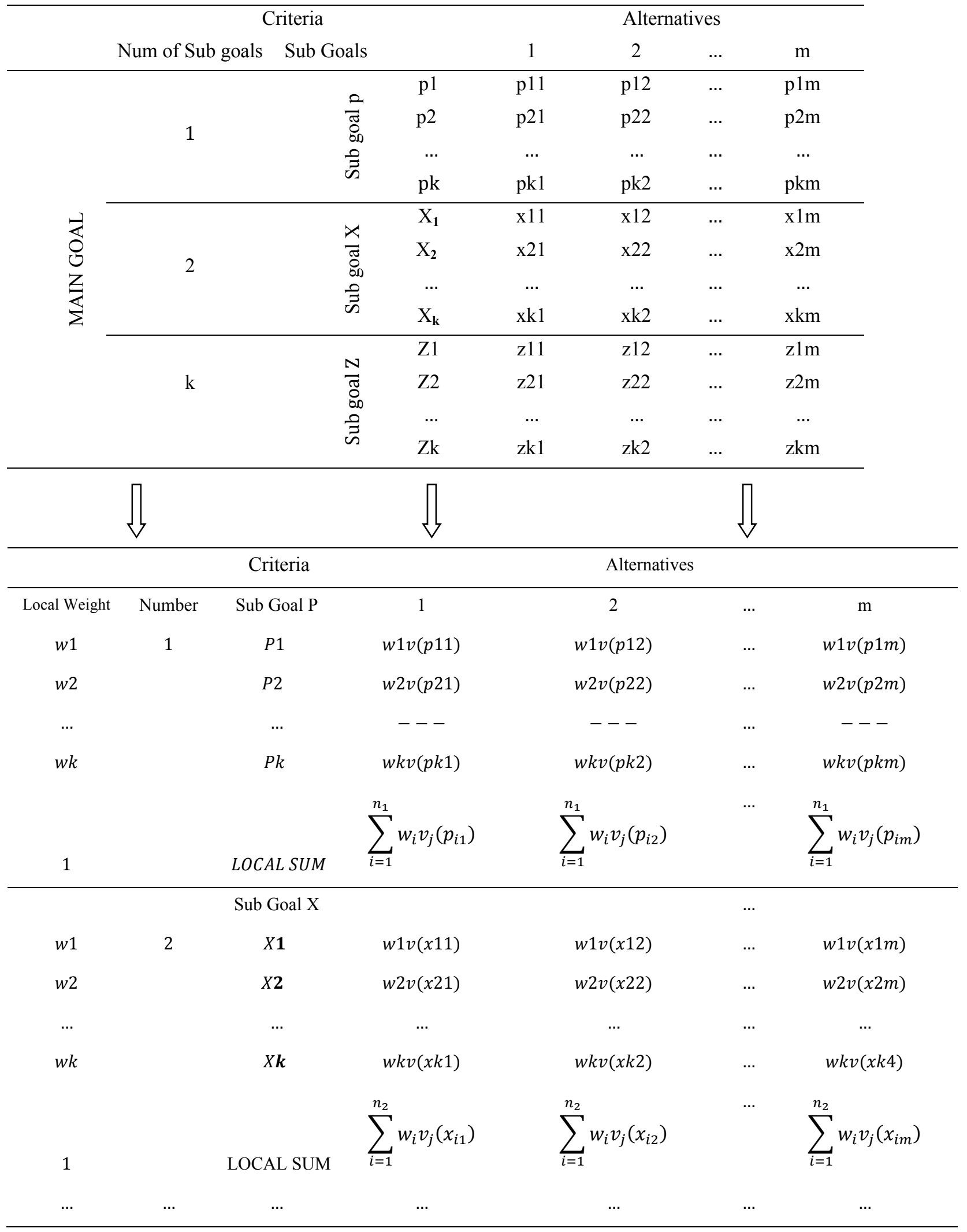




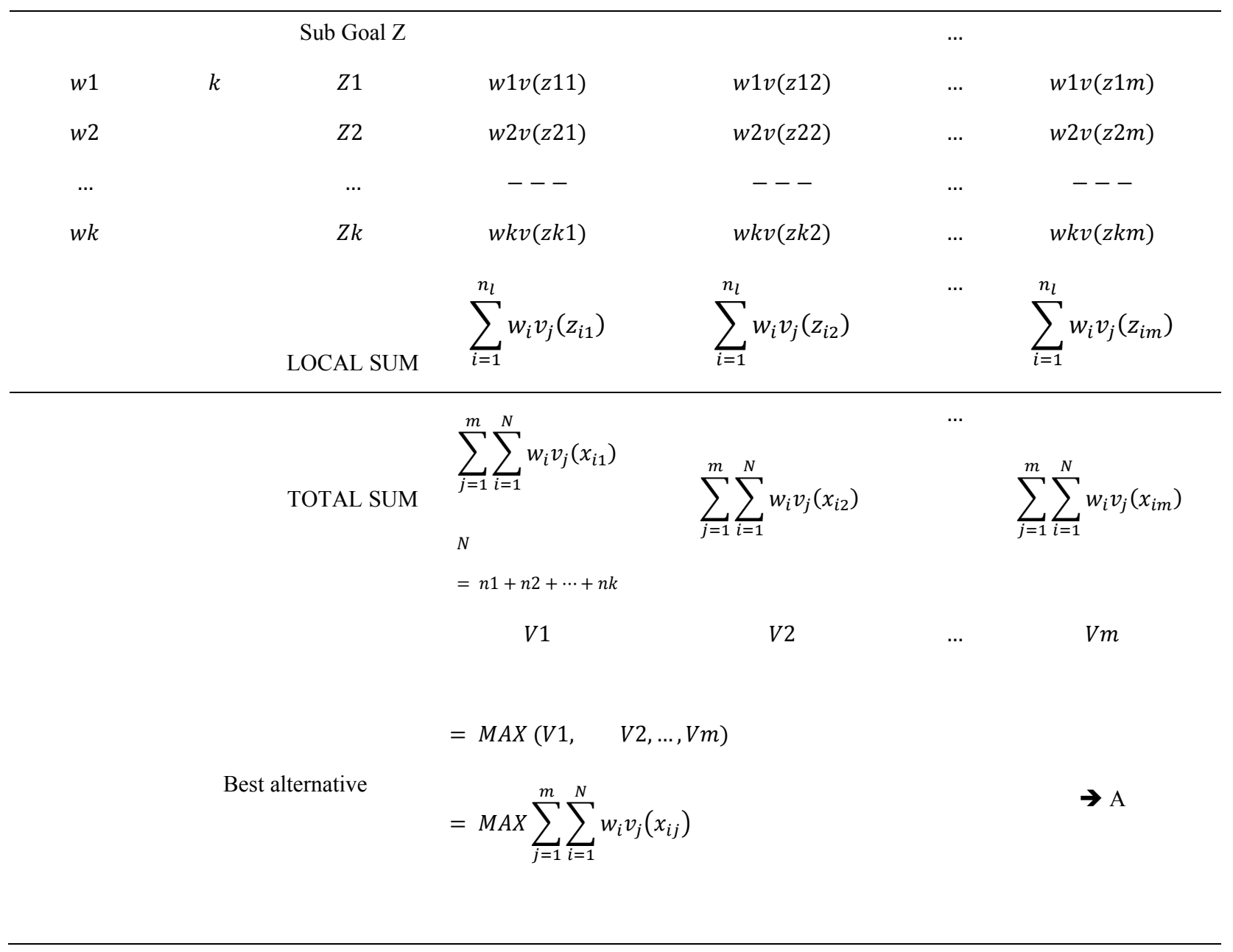

In effect, the best candidate is the alternative with the MAX Multidimensional Utility/Value Function (MUF) score.

\subsection{Step 8: Validate Solutions against Problem Statement}

Validation of inputs and results is important, and sensitivity analyses of all areas of contention must be done. Sensitivity analyses refine the solutions and produces important insights. For most problems weight determination is where there is most controversy, and this is where sensitivity analyses are concentrated. It is very rare for a final solution to be insensitive, so basically it is the wideness in the range of the weights that tells if the model is robust.

\section{Summary}

Figures 4 and 5 are decision-analytic hierarchies of the model (as done in Logical Decisions for Windows (LDW)). The figures show the main goal of Best Candidate as well as the Sub goals of Pedigree, Abilities, Politics and Imagination, and the many criteria that were used to measure the alternatives aka candidates. The number of criteria differs from the one in Table 3 because some of the criteria were further decomposed into sub-criteria to ensure better measurement.

The grid below shows what are needed to set the model into operation. The inputs are the attributes, which have been turned into the criteria by the addition of measurement levels. The alternative set is of course the list of presidential candidates.

Single Dimensional Utility functions have been developed to transform the scores of the alternatives into dimensionless utilities. These are then aggregated into Multi Dimensional Utilities which provide uni-criterion quantities for ranking alternatives.

The main output of the process is the rankings of the alternatives as to the best overall candidate. There can also be rankings to determine the candidate with the best in any of the sub-goals of 'Pedigree, Abilities, Politics and 
Imagination. There are 4 sub-goals in this iteration, but this is just a suggested number. Sensitivity analyses must be performed on the inputs especially the weights, to validate results and gauge the robustness of the model.

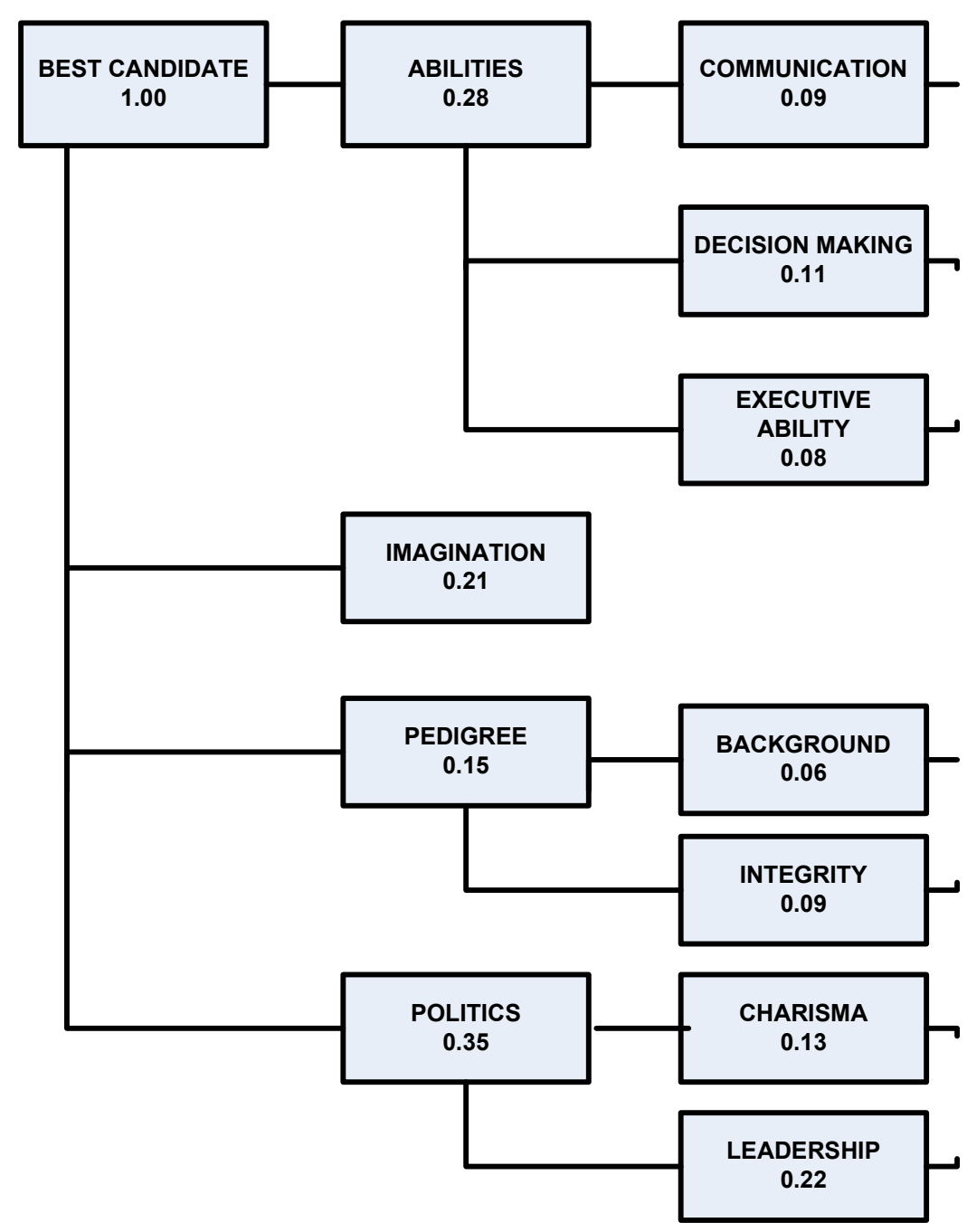

Figure 4, An LDW decision-analytic hierarchy of best candidate (without criteria) showing goals, sub goals and weights

Table 8. Operational process of determining leadership

\begin{tabular}{lccc}
\hline & INPUTS & PROCESS & OUTPUTS \\
\hline 1 & Criteria (table xx) & SUFs (MAUT/MAVT) & Rankings of alternatives on SUB GOALS \\
2 & Goals and Sub Goals (Fig xxx) & MUFs (MAUT/MAVT) & Rankings of alternatives on MAIN GOAL of Best \\
3 & Alternatives (Table $\mathrm{x}$ ) & Weights elicitation ( AHP) & Sensitivity Analyses \\
\hline
\end{tabular}




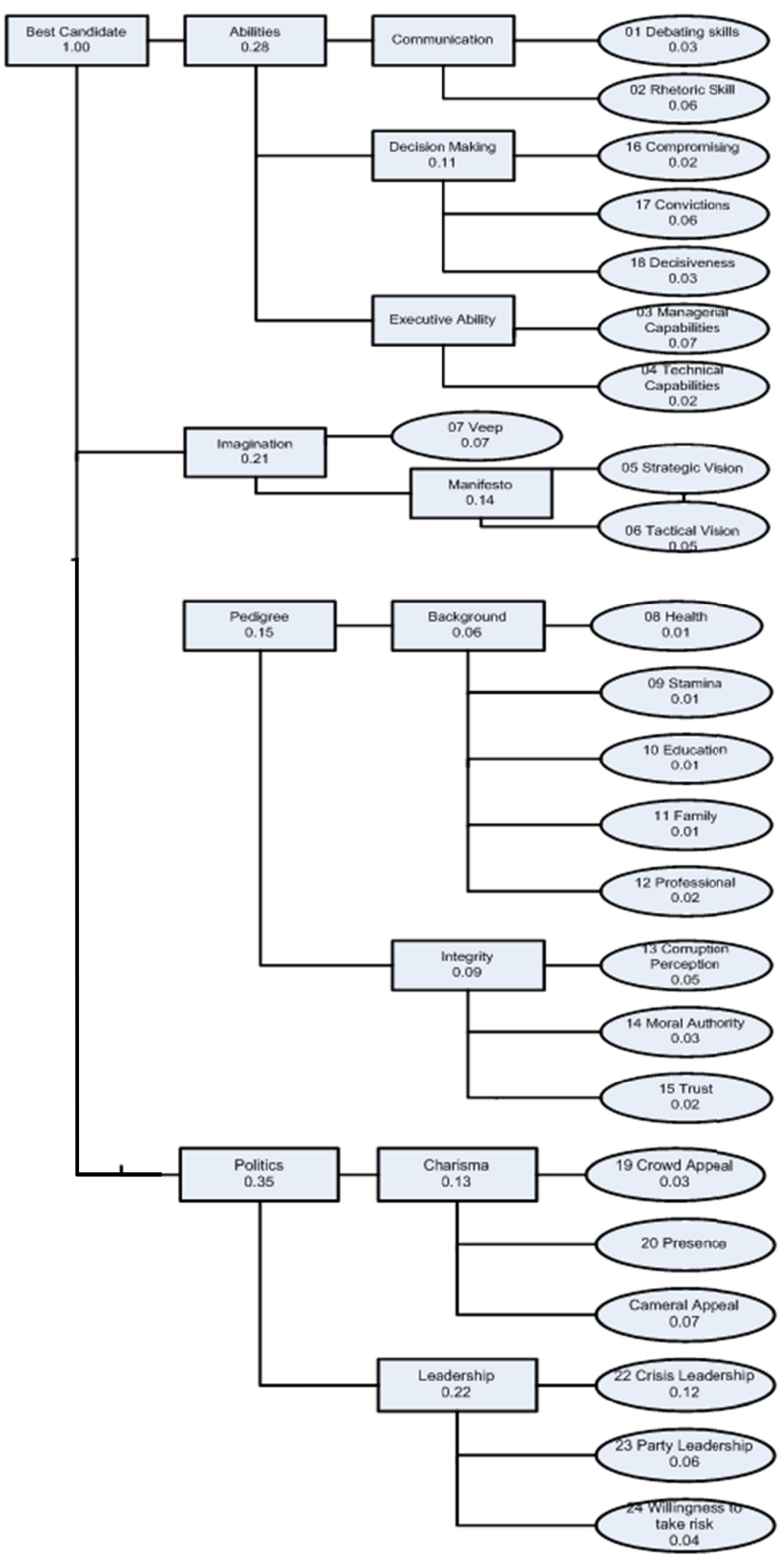




\section{Conclusion}

The process of choosing executive leaders is by far the most complex political undertaking in any country. Whilst constitutions get amended and laws get passed, the emergence of leaders has remained primitive. The high entropy, horse trading and acrimonies that have characterized politicking have been accepted as part of the process, and with these have sometimes emerged damaged goods that clearly had no business getting close to the presidency. This study attempts to assemble qualities or attributes the possession of which may indicate success and possible greatness in an aspirant. As Foti et al., 1982 espoused, 'In addition, widespread media and public scrutiny of the presidency establish leadership qualities as important determinants for presidential performance (Foti, Fraser, \& Lord, 1982)'. The implication of this deep synopsis is that there is some select set of attributes that can foretell presidential performance. The identification and assemblage of these attributes constituted one leg of the study. But the modeling of these attributes to prescribe a so-called best candidate constitute enormous research potential into how best to add value to the riotous process of selecting executive leaders.

The Optimization model below:

\section{$\operatorname{Max} \mathrm{V}(\mathrm{X})$}

$$
\text { \{Requirement set\} }
$$

$$
\text { s.t } x 1, x 2, \ldots x k>=0
$$

shows that MCDA as done here (Table 7, equation "A") is not different from regular optimization.

Below is a pertinent quote from Thomas Saaty, the proponent of AHP and ANP. "Some people say, "What is the use of learning about decision making? Life is so complicated that the factors which go into a decision are beyond our ability to identify and use them effectively". I say that is not true. We have had considerable experience in the past thirty years to structure and prioritize thousands of decisions in all walks of life. We no longer think that there is a mystery to making good decisions" (Saaty,).

It is now time for professional decision makers to put their expertise at the feet of the electorate by prescribing leadership based on the results and research of the past thirty years and beyond. In democratic governance nothing can replace voting as a means of exercising suffrage. But voters need to be equipped with information because good leadership is perhaps the single biggest driver to good governance and ultimately development, and nations especially of the developing variety cannot squander the opportunity for catching up with the developed world by persistently choosing mediocre leaders.

\section{Limitations}

Obviously basing a candidate's future effectiveness on his current state of attributions can lead to bad consequences down the road. Extrapolation is most useful when past conditions are remarkably similar to future conditions. "The late 19th and early 20th century American pragmatist philosopher Charles Sanders Peirce was the first to point out that no new idea in the world was ever produced by inductive or deductive logic. Analyzing the past, crunching the existing numbers to produce the future can do nothing more than extrapolate the future from the past. So if you stick to measuring what you can already measure, you cannot create a future that is different than the past" (Martin, 2010). Nonetheless whilst we accept that a model is not a silver bullet, we are also mindful of the supposition that "those who do not remember the errors of the past are condemned to repeat them". In essence the limitations of this tool are the limitations of every forecasting tool; the probability that the future can be totally forecast using past data is certainly less than unity.

\section{Future Research}

Where a leader goes so go the followers; and it is very important that decisions in identifying the best leaders are proactively made. Candidates for elected leadership roles of all categories must be measured analytically beyond elections. It is hoped that in a next iteration, live data will be used in the model to shadow or precede elections. For example "Obama and Romney", who will be a better leader? A well-designed MCDA model with the correct data is best placed to answer this question.

\section{References}

Ansolabehere, S., \& King, G. (1990). Measuring the Consequences of Delegate Selection Rules in Presidential Nominations. Journal of Politics, 52(2). http://dx.doi.org/10.2307/2131908

Arthur, M. S. Jr. (1997). Rating the Presidents: Washington to Clinton. Political Science Quarterly, 11(2), 179-190. http://dx.doi.org/10.2307/2657937 
Baker, D., Bridges, D., Hunter, R., Johnson, G., Krupa, J., Murphy, J., \& Sorenson, K. (2002). Guidebook to Decision-Making Methods, WSRC-IM-2002-00002. Department of Energy, USA. Retrieved from http://emi-web.inel.gov/Nissmg/Guidebook_2002.pdf

Belton, V., \& Stewart, T. J. (2002). Multiple criteria decision analysis: an integrated approach. Boston: Kluwer Academic Publishers. Retrieved from http://www.epa.gov/cyano_habs_symposium/monograph/Ch35_AppA.pdf

Carter, W. S. Defining a Path to Greatness in the Modern Presidency. Retrieved from http://www.thepresidency.org/storage/documents/Vater/Smoot.pdf

Chankong, V., \& Haimes, Y. Y. (1983). Multi-objective Decision Making Theory and Methodology. New York: Elsevier Science.

Deluga, R. J. (2001). American presidential Machiavellianism Implications for charismatic leadership and rated performance. The Leadership Quarterly, 12, 339-363. http://dx.doi.org/10.1016/S1048-9843(02)00104-2

Foti, R. J., Fraser, S. L., \& Lord, R. G. (1982). Effects of leadership labels and prototypes on perceptions of political leaders. Journal of Applied Psychology, 3, 326-333. http://dx.doi.org/10.1037/0021-9010.67.3.326

Frimpon, M. (2012). A Re-structuring of the Enterprise Resource Planning Implementation Process. International Journal of Business and Social Science, 3(1), 231-243

Grelk, B., Kloeber, J. M., Jackson, J. A., Deckro, R. F., \& Parnell, G. S. (1998). Quantifying CERCLA using site decision maker values. Remediation, 8, 87-105. http://dx.doi.org/10.1002/rem.3440080209

Harris, R. (1998). Introduction to Decision Making, Virtual Salt. Retrieved from http://www.virtualsalt.com/crebook5.htm

Keefer, D. L., Corner, J. L., \& Kirkwood, C. W. (2000). Decision Analysis Applications in the Operations Research Literature, 1990-1999.

Keeney, R. L., \& Raiffa, H. (1993). Decisions with multiple objectives: preferences and value tradeoffs. Cambridge England; New York, NY, USA: Cambridge University Press.

Kelly, T., \& Lonnstrom, D. (2010). American Presidents: Greatest and Worst, Siena's 5th Presidential Expert Poll 1982 - 2010. Retrieved from www.siena.edu/sri/research

Kiker, G. A., Bridges, T. S., Varghese, A., Seager, T. P., \& Linkov, I. (2009). Application of multi-criteria decision analysis in environmental decision making. Retrieved from http://onlinelibrary.wiley.com/doi/10.1897/IEAM_2004a-015.1/full

Kirkwood, C. W. (1997). Strategic Decision Making: Multi-objective Decision Analysis with Spreadsheets. Belmont: Duxbury Press.

Martin, R. (2010). Management by Imagination. Retrieved from http://blogs.hbr.org/martin/2010/01/management-by-imagination.html

Morgan, I. UK Survey of US Presidents: Results and Analysis. Institute for the study of the Americas.

Mortensen, H. C. (2007). John F. Kennedy - Leadership Qualities that Moved A Nation (Master's thesis). University of Pittsburgh, USA.

Moss, J. Jr., \& Johansen, B. (1991). Conceptualizing leadership and assessing leader attributes. Berkley, CA: National Center for Research in Vocational Education.

Murray, R. K., \& Tim, H. B. (1994). Greatness in the White House: Rating the presidents from George Washington through Ronald Reagan (2nd ed.). University Park, PA: Pennsylvania University Press.

Nishizaki, et. al. (2004). Sensitivity Analysis Incorporating Fuzzy Evaluation for Scaling Constants of Multiattribute Utility Functions in Multiplicative Form. MCDM 2004. Whistler, B. C., Canada.

$\begin{array}{llll}\text { Presidential } & \text { Ages. } & \text { (2010). } & \text { Retrieved }\end{array}$ http://theticklish.blogspot.com/2011/03/ages-of-90-presidents-across-world.html

Saaty, T. L. (1990). How to make a decision: The Analytic Hierarchy Process. European Journal of Operational Research, 48, 9-26. http://dx.doi.org/10.1016/0377-2217(90)90057-I

Schmitt, C., Dengler, D., \& Bauer, M. The Maut Machine: An Adaptive Recommender System. Retrieved from http://citeseerx.ist.psu.edu/viewdoc/summary?doi=10.1.1.85.2087 
Sica, E. T., Brigatto, G. A. A., Carmargo, C. C. B., Palma, A. S., Carvalho, R. T., \& Okuda, B. S. Multi-attribute Value Function for the Assessment of Distributed Generation Projects; application to technical criteria. Retrieved from http://www.labplan.ufsc.br/congressos/Induscon\%202010/fscommand/web/docs/T1029.pdf

Teven, J. (2008). An Examination of Perceived Credibility of the 2008 Presidential Candidates: Relationships with Believability, Likeability, and Deceptiveness. Human Communication. A Publication of the Pacific and Asian Communication Association, 11(4), 383-400.

Theakston, K., \& Gill, M. (2005). Rating 20th Century British Prime Ministers. POLIS Working Paper, 19. http://dx.doi.org/10.1111/j.1467-856X.2006.00220.X

UK DTLR. (2001). Multi Criteria Analysis: A Manual, Department for Transport, Local Government and the Regions, $U K$.

Retrieved

from http://www.odpm.gov.uk/stellent/groups/odpm_about/documents/page/odpm_about_608524.hcsp 